\title{
Briquettes Production as an Alternative Fuel
}

\author{
U.S.P.R. Arachchige \\ Department of Civil and Environmental Technology, Faculty of Technology, University of Sri Jayewardenepura, \\ Homagama, Sri Lanka \\ $\dagger$ Corresponding author: U.S.P.R. Arachchige; udara@sjp.ac.lk
}

Nat. Env. \& Poll. Tech.

Website: www.neptjournal.com

Received: $30-12-2020$

Revised: $12-03-2021$

Accepted: 10-04-2021

Key Words:

Alternative fuel

Briquettes

Energy management

Agricultural crop residue

Waste management

\section{ABSTRACT}

Bioenergy, which originated from agricultural crop residue and industrial waste, has been studied for sustainable energy generation. As a raw material for briquettes production, agricultural-crop residue, industrial waste, sewage, sludge, or other plants can be used. Briquettes have numerous advantages as they directly help to reduce waste generation and handling. The possibilities of the briquetting, qualities, and other essential factors for briquette production have been discussed. The alternative methods of Briquetting have been addressed with the comparison. The characteristics of the raw materials for briquettes production have been discussed to identify the best agricultural crop residue for briquettes. The properties of binding agents for the briquetting process have been discussed to identify the most practically available binding agent.

\section{INTRODUCTION}

Coal, oil, and natural gas, which are considered fossil fuels, are the primary energy sources that drive the global energy demand process, providing 80 percent of global energy demand until today (Kpalo et al. 2020). Depletion of fossil fuels is at an alarming rate, with environmental pollution concerns as a global issue.

Atmospheric greenhouse gas concentration has been rapidly increasing with industrialization. The greenhouse gas concentration and fossil fuel combustion have a significant relationship with each other (Udehl \& Kidak 2019). It has been noted that petroleum, coal, and oil directly contribute to greenhouse gas emissions and global warming.

Renewable energy shows better sustainability while comparing with non-renewable energy sources. Because of global warming and the effects of climate change, the majority of developed countries are shifting to renewable energy sources (Rabbani et al. 2017). Developing countries, on the other hand, continue to lag, despite having high renewable energy sources such as hydropower, biomass, biogas, and other bioenergy sources.

Biomass is one of the primary fuels used for day-to-day life as it is the most precious and versatile resource on earth (Government of Canada 2017). From the day man discovered fire, biomass has been used as a fuel source. One of the main applications of biomass is biomass boilers for industrial applications. Most industries are currently using biomass boilers to produce steam for industrial processes. Biomass is the most widely used fuel source for heating, cooking, and industrial steam generation (Arachchige \& Sandupama 2019). There are varieties of biomass available with different physical properties, given in Fig. 1. Industries based on biomass can foster rural development while providing employment opportunities for the public (Zafar 2016). However, at the same time, the biomass's re-growth has to be promoted to continue that as a sustainable energy source. Numerous applications depend on biomass either for power, steam, or heat generation; however, due to financial benefits, deforestation is alarming around the world by destroying all-natural resources (Scarlat \& Dallem 2015). The negative aspects of conventional biomass utilization in developing countries can be mitigated by promoting up-to-date technologies, such as waste-to-energy technologies. Most of the waste generation at industrial premises and agricultural processes plays a vital role in sustainable biomass generation.

One of the main issue with industries are solid waste generated in the industrial process. The majority of industries either incinerate solid waste at a high temperature or dump it in the open ground. At the same time, solid waste and sludge are used for fertilizer production due to biodegradable components. Simultaneously, the solid waste composition is essential if it is to be recycled or used in the manufacturing of biodegradable fertilizer (Abdel-Shafy \& Mansour 2018). 


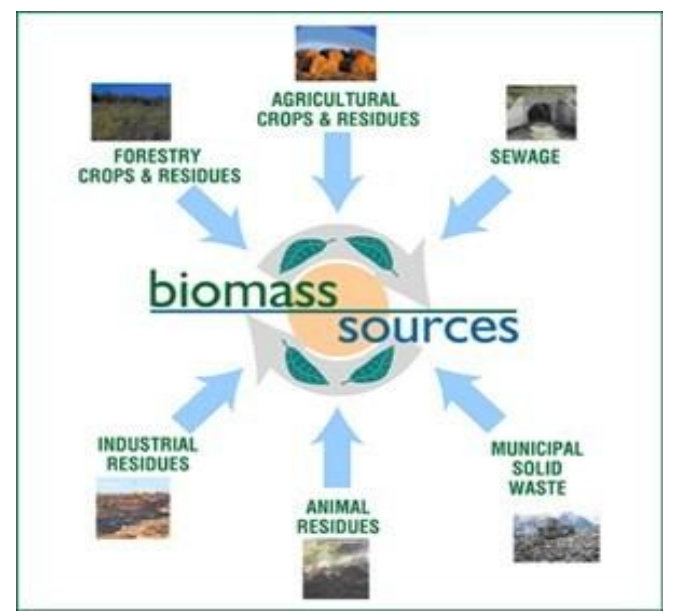

Fig. 1: Biomass sources.

Time is the most crucial factor for the bio-degradation of solid waste as it needs enormous storage capacity until it reaches the final stage (Abdel-Shafy \& Mansour 2018).

One of the proven ways of generating energy from waste and converting waste into a sustainable way is biomass briquettes' production (Onukak 2017). Different types of waste have been considered for the production of the briquettes to manage solid waste sustainably. Municipal solid waste has been used to simulate biomass briquettes to produce onsite energy (Romallosa \& Kraft 2017). Sawdust, date palm trunk, and various plastic wastes have been used to create biomass briquette without a binding agent (Garrido et al. 2017). They have used locally available solid waste to minimize waste handling.

At the same time, in Uganda, Lubuwama \& Yiga (2017) used groundnut shells and bagasse to produce briquettes while Mereteet al. (2014) from Ethiopia made briquettes from coffee husks and pulp.

Biological sludge, cotton flock, and sawdust can produce briquette with binding agents such as shredded paper, organic waste, and citrus peel. Water is commonly used as the principal raw material in the production of all types of briquettes to evenly combine all of the raw materials. The dust created during the briquette production process with charcoal is detailed in the literature (Britta Peters 2014). If briquettes are perfectly produced, they should pass the durability test as follows in Fig. 2 (Britta Peters 2014). The raw material selection for briquetting has to be performed based on the one that has better fuel properties (Mu'az1 2016).

To improve the density of bulky material, briquetting can be done using manual hand pressing and mechanical compaction. The form is defined by converting the fine particles.

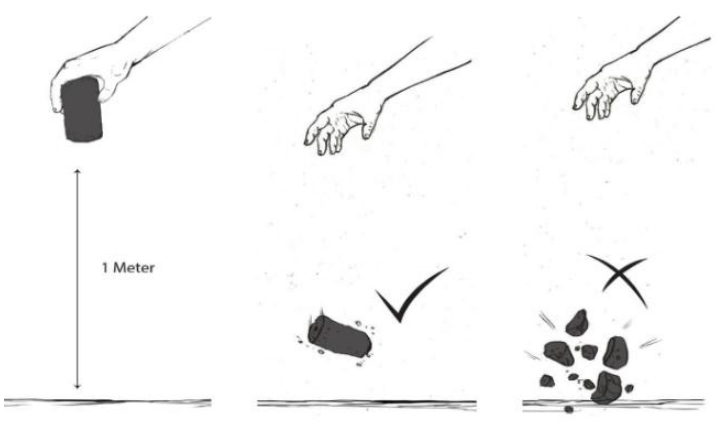

Fig. 2: Testing durability of the briquettes.

Briquette's higher density will prevent the separation of combined material into separate parts during transportation, storage, and combustion. Briquette's moisture content should be maintained between $6-16 \%$, as mentioned in the literature (ASTM Standard E711 - 87 2004).

Biomass briquettes have been demonstrated to be one of the most efficient energy sources. Many different types of waste have been used to make briquettes. Other raw materials have been used in the biomass briquette manufacturing process in a number of studies. The quality and the dimensions of the biomass briquette depend on the raw material type and the production process. The quality of the briquette depends on the characteristics of the raw materials used to produce the briquettes. The key elements of the production of the successful briquettes include the moisture content of the raw material and the calorific value of the raw material.

\section{MATERIALS AND METHODS}

Biomass handling at home or industries is not attractive as it occupies larger ground space than fossil fuels. The way agro waste, industrial waste, sewage, or sludge is handled is not environmentally friendly because it is produced at a higher rate. One of the most attractive ways of applying biomass for industrial energy generation is to convert the biomass energy source to briquette, which takes less space. Garrido et al. (2017) used sawdust, date palm trunk, and various plastic waste without a binding agent. One of the main advantages of converting low-density biomass into high-density briquette is that it consumes less storage space while providing higher calorific value. Briquettes are easy to transport, easy to store, and easy to use or generate energy for heating or power generation.

A high-quality fuel source should have a higher density for a longer time of the burning process (Onukak et al. 2017). Furthermore, durability is an important feature because it is linked to the handling, transportation, and storage of the product until the final burning process. One of the 
most important aspects to consider when evaluating the best briquette is the time it takes for water to boil. Water boiling is the time taken to boil a specific amount of water when a particular briquette amount is used. If the water boiling time is less, less fuel is required for the combustion process (Onukak et al. 2017). The burning rate is also an important factor in briquette classification since a high burning rate necessitates a large amount of fuel to complete the combustion process. Moreover, thermal efficiency is the most significant physical property because it is directly related to calorific value (Onukak et al. 2017).

There are multiple raw materials available for briquettes production, such as municipal solid waste, industrial waste, sludge, agricultural crop residue, etc. Production of fuel briquettes using municipal solid waste has proven to be an economical product (Diener et al. 2014, Shafie et al. 2012). The quantity of solid waste reduces production costs while also helping to reduce pollution. The properties of the final product are directly linked to the raw material used to make the briquette. Industrial waste plays a significant role in raw material supply in briquettes production. From sawmills as sawdust, rice mills as rice husk, garments produce as flocks and cotton dust, and the water treatment sludge at the industries are the primary sources of raw materials for the briquettes production process. Even septic tank sewage is also a possible source of raw material for briquette production with higher calorific value.

The sludge's higher moisture content is the main issue with the sludge as a raw material as that decreases the calorific value of the product. However, higher moisture content sludge can be used as a binding agent with the municipal solid waste to produce briquettes with higher calorific value. Table 1 summarizes the possible raw materials for fire briquettes production (Diener et al. 2014, Shafie et al. 2012).

Mainly, two analyses have to be done to verify the raw materials for briquettes - proximate analysis and ultimate analysis. The proximate analysis provides the potential efficiency and the durability of the briquettes produced.

Table 1: Raw materials for briquettes.

\begin{tabular}{|ll|}
\hline Origin & Raw materials for briquettes \\
\hline Agricultural waste & $\begin{array}{l}\text { Coconut fronds, coconut fiber (coir), Cas- } \\
\text { sava stalk or leaves, corn stalk, rice straw, } \\
\text { palm oil frond, sugar cane leaves }\end{array}$ \\
$\begin{array}{l}\text { Industrial residue from } \\
\text { agriculture }\end{array}$ & $\begin{array}{l}\text { Sugar cane bagasse, coconut shells, Oil } \\
\text { palm husk, paddy husk, corn cobs, coffee } \\
\text { husk, peanut shells }\end{array}$ \\
Other Industrial waste & $\begin{array}{l}\text { Water treatment Sludge, cotton flocks, } \\
\text { Sewage, Sawdust, paper waste }\end{array}$ \\
Other materials & Coal ash or fly ash, charcoal powder \\
\hline
\end{tabular}

Several physical properties have to be estimated and evaluated for the solid waste, such as total carbon content, volatile matter, fixed carbon, ash content, moisture content, bulk density, particle size, and the calorific value to analyze the proximate analysis (Emerhi 2011).

Total carbon content: The total carbon content represents the amount of carbon available in the waste material, which could be burned for releasing heat.

Volatile matter: High volatile matters are immediately released when the biomass is heated up. Therefore, low volatile matter is essential to complete the combustion process.

Fixed carbon: This factor defines the total amount of solids remaining once the carbonization process has been completed. It should be a higher value of carbon content in the feedstock to produce long-lasting and stable briquettes.

Ash content: A higher quantity of the feedstock's ash content maintains the burning device's operating temperature by ash slagging. The operating temperature maintained at the required level is essential to avoid the unit's overheating to keep the combustion process without interruptions.

Moisture content: Higher moisture content in the feedstock will eventually increase the production cost, hence, moisture must be removed from a feedstock for quality briquette manufacturing. However, a lower amount of moisture is also not suitable as that will decrease the density by forming flakes.

Bulk density: A higher bulk density is required to keep the resistance for shear stress, which causes the product>s durability.

Particle size: The raw materials bonding ability increases with the smaller particle size of the raw material. Simultaneously, bonding ability can increase by using different raw material particle sizes for briquette production.

Calorific value: The amount of energy in the briquette represents the raw materials> calorific value. According to the above information, lower moisture content, lower volatile matter and less ash content, higher fixed carbon content, and bulk density are essential to produce efficient fire briquettes (Enweremadu et al. 2004).

Moreover, the ultimate analysis is vital to identify the raw material (waste material) of the briquette production process. Ultimately those factors will contribute to the emissions releasing into the atmosphere when briquettes undergo the combustion process.

Carbon monoxide: The low combustion temperature and poor mixing of the fuel and air will result in Carbon Monoxide (CO) generation. 
Fine particulate matter: Emissions of the fine particle is a result of low combustion temperatures.

Nitrogen Oxides: There is a direct relationship between the Nitrogen content of the feedstock and the nitrogen oxide emissions.

Sulfur oxides: Like the nitrogen content of the fuel, the raw materials' sulfur content is directly related to the feedstock's sulfur dioxide emissions.

Therefore, the feedstock's sulfur and nitrogen content must produce a fire briquette with less environmental pollution.

The proximate analysis has to be performed before the production process to select better feedstock (Chin \& Siddiqui 2004). Like the nitrogen content of the fuel, the raw materials' sulfur content is directly related to the feedstock's sulfur dioxide emissions (Lela et al. 2016). Therefore, the feedstock's sulfur and nitrogen content must produce a fire briquette with less environmental pollution (Lela et al. 2016). Some fundamental parameter values of the feedstock for briquetting have been reported in the literature, as shown in Table 2 (Ortz et al. 2013).

\section{RESULTS AND DISCUSSION}

To keep the moisture content of the feedstock, the raw materials for briquettes must be dried. Even natural storage conditions over a longer length of time can do this. It's critical to take advantage of the storage time to use natural drying to reduce moisture content. The necessary steps of the briquette production are milling or shredding the raw materials, drying, and pressing to create a final product (Lela et al. 2016).

Table 2: Properties of the raw materials.

\begin{tabular}{|llll|}
\hline & Properties & Unit & Requirement \\
\hline Proximate & Moisture Content & $\%$ & $6-14$ \\
Analysis & Ash Content & $\%$ & $<4$ \\
& Particle size & $\mathrm{mm}$ & $1-10$ size with \\
& & & $10-20 \%$ powdery \\
& Fixed carbon & $\%$ & $9-25$ \\
& Calorific value & $\mathrm{MJ} / \mathrm{kg}$ & $10-35$ \\
& Bulk density & $\mathrm{Kg} / \mathrm{m}^{3}$ & $>50$ \\
& Heating value & $\mathrm{MJ} / \mathrm{kg}$ & $12-20$ \\
& Volatile matter & $\%$ & $50-90$ \\
Ultimate & Carbon $(\mathrm{C})$ & $\%$ & $40-55$ \\
& Hydrogen $(\mathrm{H})$ & $\%$ & $5-8$ \\
& Oxygen $(\mathrm{O})$ & $\%$ & $35-48$ \\
& Nitrogen $(\mathrm{N})$ & $\%$ & $0-1$ \\
& Sulfur $(\mathrm{S})$ & $\%$ & $0-2$ \\
& Chloride $(\mathrm{Cl}$ & $\%$ & $0-1$ \\
\hline
\end{tabular}

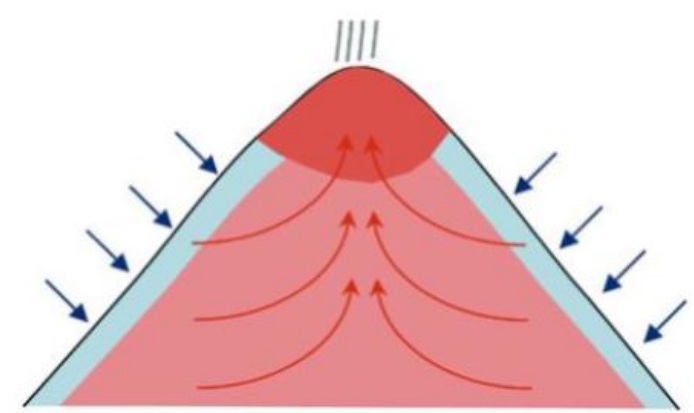

Fig. 3: The chimney effect - natural drying of a biomass heap.

Simultaneously, to achieve better drying conditions, raw materials storage should be done with cement or concrete platforms to avoid missing sand and other unwanted particles. Simultaneously, the storage area must be covered with fabric to prevent moisture from contacting and trapping the heat to vaporize the moisture (Lela et al. 2016). It can be used to maintain the moisture content of the feedstock by pre-drying it before pressing. Natural drying can be applied to minimize the moisture content of the raw material. The raw material can be directly exposed to solar heating or by supplying hot air through the raw material storing pile. The most traditional way of doing the natural heap drying is to use the chimney effect by creating a channel at the heap center for air passing (Fig. 3) (Lela et al. 2016).

Raw material preheating to maintain moisture content is an essential factor while considering the briquette. According to the literature, the moisture content of raw materials should be between $6 \%$ and $23 \%$ to ensure proper briquette production, as low moisture produces roughness. High moisture, on the other hand, increases the energy cost of moisture removal (Stolarski et al. 2013, Zhang et al. 2013).

The particle size of the raw material is important for the long-term durability of the briquettes produced. Filling the empty spaces between each particle with a mixture of particle sizes is a well-known approach. Previous research has found that particle sizes of less than $6 \mathrm{~mm}$ are best for mixing raw materials. (Andrejko \& Grochowicz 2007).

Preheating the raw material before pressing is essential to maintain the moisture content, increase the grind ability, avoid difficulties during transportation, and increase the final product (Li et al. 2007, Kaliyan \& Vance Morey 2009, Kaliyan \& Vance Morey 2010).

Compacting or pressing is the heart of the briquette production to increase the density (densification). According to the plant's size, there are numerous ways to achieve the compacting by the manual or automated way. Piston briquetting is one of the most common processes, in which crushed biomass is pushed into a cylinder mold by a piston driven by a flywheel (Fig. 4) (MaxTon Industrial Co 2020). 


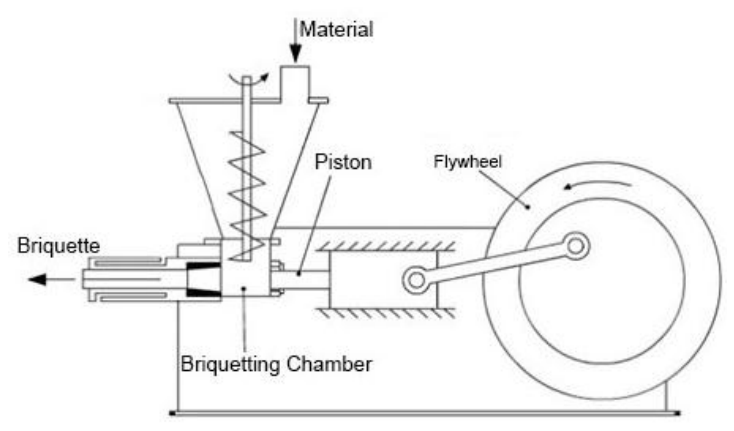

Fig. 4: Piston pressing briquetting machine.

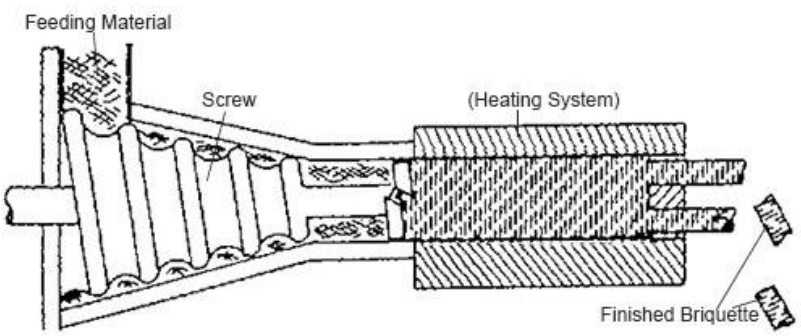

Fig. 5: Screw pressing briquette machine (MaxTon Industrial Co. 2020).

The piston reciprocates the piston using the device's rotary power, and it pushes the ram to reciprocate in the forming sleeve to provide a force that forms the briquette to the size and shape defined. The briquetting machine's screw-type can be used similarly to the piston pressing by applying the force to create briquettes (Fig. 5).

One of the most common types of briquetting is a roller-type pressing machine similar to Fig. 6. Closer contact between tow rollers allows them to perform more efficiently. Both rollers have surface holes that coincidently intersect while rotating in the opposite direction. The rollers move at

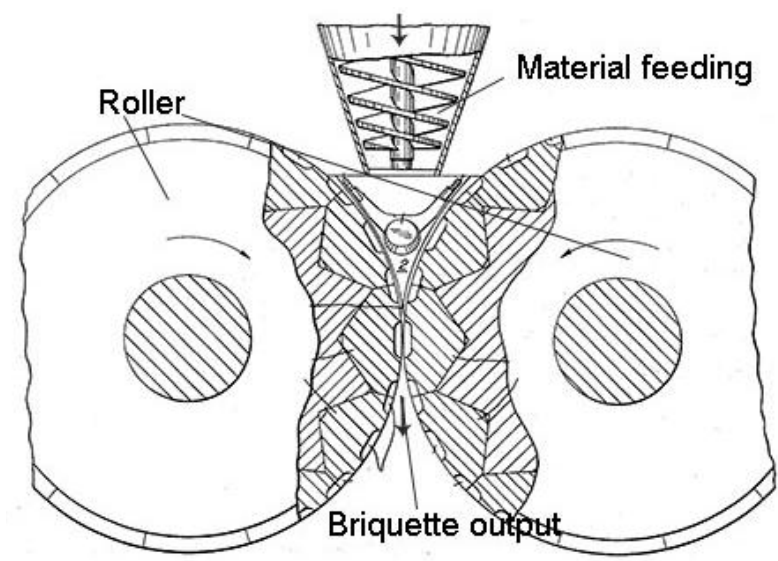

Fig. 6: Roller-type briquetting machine (MaxTon Industrial Co 2020). the same speed and opposite direction. When they move in the opposite direction, two holes of both rollers meet in the middle of the machine and press the raw material to form the briquette.

According to the waste material and the economic condition, one of the methods mentioned can be applied to produce briquettes. However, the automated process is preferred as that can be used to apply stable high pressure for densification.

The hydraulic type works with a hydraulic pump station which supplies tremendous pressure. With its high pressure, almost all the materials can be briquetted with this system (Fig. 7). One of the advantages of the hydraulic system is briquetting can be produced even with the absence of water due to high pressure applied to raw materials. The briquette working process is in a chamber where materials are fed into; materials are briquetting under very high pressure. It causes their plasticity and causes them to bind together as a block in a stable manner. To keep time on the briquette, the hydraulic type requires a high level of pressure. This avoids short-term material deformation rebound and generates special heating for materials like sawdust to melt its interior lignin, resulting in a stronger briquette.

\section{A. Binders}

During the briquetting process, raw material densification will not be entirely stable due to particle distraction. Therefore, binding agents are essential to create internal bonding between the particles during densification. Binders help in obtaining sufficient strength for the finished briquette; with the use of binders, raw material particles are densified, resulting in strong briquettes. The number of binders added to the raw material varies according to the raw materials' properties and the binding agent. The use of an automated briquette machine with high pressure would reduce the use of a binding agent. There are plenty of binding agents reported

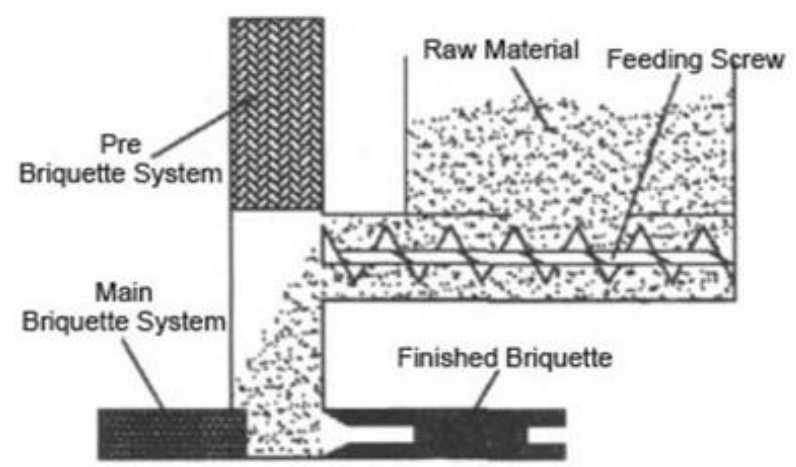

Fig. 7: Hydraulic type briquetting machine (MaxTon Industrial Co 2020). 
in the literature that starts from lignin, biodegradable paper soaked in water, char, glycerin, molasses, cassava starch, wheat starch, and waste cooking oil (Bazargan et al. 2004, Massaro et al. 2014, Okegbile et al. 2014, Haykiri-Acma et al. 2013, Njenga et al. 2013, Prasityousil \& Muenjina 2013, Fengmin \& Mingquan 2011, Chou et al. 2009, Hedman et al. 2005, Rubio et al. 1999). Moreover, material that contains lignin has a better chance for briquetting without a binder agent as that lignin itself acting as a binding agent. Therefore, it is essential to analyze the raw feedstock's lignin content to identify whether external binding agents are necessary or not (Rubio et al. 1999).

\section{B. Quality Parameters}

To determine whether a product is suitable for combustion, a few factors must be addressed.

- The average time for briquettes to ignite plays a significant role as that represents the ignition of the briquette.

- Time is taken for the cooking process with a certain briquette or briquette requirement to complete the specific application.

- Soot formation and the ash generated are important as they are directly related to the amount of heat supply to the application.

- Flue gas emission analysis is important to understand environmental pollution compared with conventional biomass.

- Odor during the combustion process will produced when used for household cooking and industrial heating.

There are significant physical parameters of briquettes to measure to compare and categorized as a quality product. The briquette density is one of the most important parameters as it defines the briquette's energy content (Kpalo et al. 2020).

The feedstock and binding agent density, operating pressure, temperature, and water content will decide the product's eventual density. Based on the density, the total energy content in one unit is varied. Moreover, the burning time of the briquette also $i$

ontent is an important parameter that impacts the density of the final product. Moreover, the higher moisture content will lead to a lower calorific value (Miranda et al. 2015). However, a significantly lower moisture limit also leads to lower quality as it will burn out very fast without generating proper energy (Ahmad et al. 2018). Simultaneously, moisture content that is less than $4 \%$ or $5 \%$ will reduce stability (Tumuluru et al. 2011). The suitable moisture content is around $8 \%$ is suggested by many of the previous studies as it will overcome previously explained drawbacks (Chin \& Siddiqui 2004).

The compressive index can also be used to determine the briquette's stability and quality, as well as its transport and storage capabilities (Gendek et al. 2018). Compressive strength is the maximum crushing load a briquette can withstand before cracking or breaking into pieces. However, compressive strength will depend on the material's particle size, water content, operating pressure and temperature, and the type of the material (Gendek et al. 2018). The compressive strength value can be varied between $10-22$ MPa according to the raw material and the production steps. Among all the factors, the most important one is the final product's calorific value, which will decide the briquette's energy content (Romallosa 2017). The calorific value of the briquette is reported between $13-16 \mathrm{MJ} . \mathrm{kg}^{-1}$ (Gill et al. 2018).

\section{CONCLUSIONS}

Briquettes production can be considered as one of the essential waste management practices. Most developing countries have agricultural waste as crop residue or industrial waste as sludge or sewage. The most applicable energy generation in those countries is based on biomass and fossil fuel. However, waste disposal practices are in a deplorable situation in developing countries. As a result, reusing waste to make fire briquettes will improve environmental quality and sustainability while lowering energy generation costs by providing employment opportunities for those living in rural areas. There are multiple raw materials available for briquette production, ranging from industrial sludge, sewage, agro waste, industrial wastes such as sawdust, paddy husk, or cotton flock in the garment industry. The quality of the raw material has to be pre-checked before starting the production process. Multiple physical and chemical properties have to be analyzed to define the production process's operating condition to maintain the moisture content, durability, or stability at the densification stage. The production process of the briquette can be achieved by many different technologies such as piston pressing, screw pressing, roller type pressing as automated, or using manual pressing with the metal mold. During the combustion process and after the combustion process, other qualities such as time taken to ignite, amount of fuel consumption, soot formation, ash remaining, smoke and flue gas analyzing, and odor must be considered to identify the quality of the briquette. Briquetting technology is yet to receive substantial attention in many developing countries with commercial success because of the technical constraints involved and the lack of knowledge to adapt the technology to suit local conditions. 


\section{REFERENCES}

Abdel-Shafy, H.I. and Mansour, M.S.M. 2018. Solid waste issue: Sources, composition, disposal, recycling, and valorization. Egypt. J. Pet., 27: $1275-1290$

Ahmad, K.K.Z., Sazali, K. and Kamarolzaman, A. 2018. Characterization of fuel briquettes from banana tree waste. In Materials Today: Proceedings; Elsevier Ltd.: Amsterdam, The Netherlands, 21744-21752.

Andrejko, D. and Grochowicz, J. 2007. Effect of the moisture content on compression energy and strength characteristic of lupine briquettes. J. Food Eng., 83(1): 116-120.

Arachchige, U.S.P.R. and Sandupama, P.W.S. 2019. Alternative fuel for biomass boilers in Sri Lanka. Int. J. Chem. Stud., 07: 729-733.

ASTM Standard E711 - 87. 2004. Standard test method for gross calorific value of refuse-derived fuel by the bomb calorimeter: Annual Book of ASTM Standard [Online]. Available: http//www.astm.info/standard/ E711.Htm2004. [Accessed on: 27/10/2020].

Bazargan, A., Rough, S.L. and G. McKay. 2004. Compaction of palm kernel shell biochars for application as solid fuel. Biomass and Bioenerg., 70: 489-497.

Britta, P. 2014. Charcoal Briquette Production: A Practical Training Manual. UN-Habitat, Nairobi, pp. 1-21

Chin, O.C. and Siddiqui, K.M. 2004. Characteristics of some biomass briquettes prepared under modest die pressures. Biomass Bioenerg., 18: 223-228.

Chou, C.S., Lin, S.H., Peng, C.C. and Lu, W.C. 2009. The optimum conditions for preparing solid fuel briquette of rice straw by a pistonmold process using the Taguchi method. Fuel Process. Technol., 90(7-8): 1041-1046.

Diener, S., Semiyaga, S., Niwagaba, C.B., Muspratt, A.M., Gning, J.B., Mbéguéré, M., Ennin, J.F., Zurbrugg, C. and Strande, L. 2014. A value proposition: Resource recovery from fecal sludge: Can it be the driver for improved sanitation? Resour. Conserv. Recycl., 88: 32-38.

Emerhi, E.A. 2011. Physical and combustion properties of briquettes produced from sawdust of three hardwood species and different organic binders. Adv. Appl. Sci. Res., 2(6): 236-246.

Enweremadu, C.C., Ojediran, J.O., Oladeji, J.T. and Afolabi, L.O. 2004. Evaluation of energy potentials in husk from soybean and cowpea. Sci. Focus, 8: 18-23.

Fengmin, L. and Mingquan, Z. 2011. Technological parameters of biomass briquetting of macrophytes in Nansi Lake. Energy Procedia, 5:24492454.

Garrido, M.A., Conesa, J.A. and Garcia, M.D. 2017. Characterization and production of fuel briquettes made from biomass and plastic wastes. Energies, 10: 850-860.

Gendek, A., Aniszewska, M., Malat'ák, J. and Velebil, J. 2018. Evaluation of selected physical and mechanical properties of briquettes produced from cones of three coniferous tree species, Biomass Bioenerg., 117, 173-179.

Gill, N., Dogra, R. and Dogra, B. 2018. Influence of moisture content, particle size, and binder ratio on quality and economics of rice straw briquettes. Bioenerg. Res., 11: 54-68.

Government of Canada. 2017. Biomass Resources [Online]. Available: https://www.nrcan.gc.ca/energy/energy-sources-distribution/ renewables/bioenergy-systems/biomass-resources/7389, [Accessed on:16/10/2020].

Haykiri-Acma, H., Yaman, S. and Kucukbayrak, S. 2013. Production of bio briquettes from carbonized brown seaweed. Fuel Process. Technol., 106: 33-40.

Hedman, B., Burvall, J., Nilsson, C. and Marklund, S. 2005. Emissions from smallscale energy production using co-combustion of biofuel and the dry fraction of household waste. Waste Manage., 25(3): 311-321.

Kaliyan, N. and Vance Morey, R. 2009. Factors affecting strength and durability of densified biomass products. Biomass Bioenerg., 33(3): 337-359.
Kaliyan, N. and Vance Morey, R. 2010. Densification characteristics of corn cobs. Fuel Processing Technology, 91(5): 559-565.

Kpalo, S.Y., Zainuddin, M.F., Abd Manaf, L. and Roslan, A.M. 2020. Production and characterization of hybrid briquettes from corncobs and oil palm trunk bark under a low-pressure densification technique. Sustainability, 12: 2468.

Kpalo, S.Y., Zainuddin, M.F., Abd Manaf, L. and Roslan, A.M. 2020. A review of technical and economic aspects of biomass briquetting. Sustainability, 12: 4609.

Lela, B., Bariši'c, M. and Nižeti'c, S. 2016. Cardboard/sawdust briquettes as biomass fuel: Physical-mechanical and thermal characteristics. Waste Manage., 47: 236-245.

Li, H., Liu, X., Legros, R., Bi, X.T., Jim Lim, C. and Sokhansanj, S. 2007. Pelletization of torrefied sawdust and properties of torrefied pellets. Appl. Energ., 93: 680-685.

Lubuwama, M. and Yiga, V.A. 2017. Development of groundnut shells and bagasse briquettes as sustainable fuel sources for domestic cooking applications in Uganda. Renew. Energy, 111: 532-542.

Massaro, M.M., Son, S.F. and Groven, L.J. 2014. Mechanical, pyrolysis, and combustion characterization of briquetted coal fines with municipal solid waste plastic (MSW) binders. Fuel, 115: 62-69.

MaxTon Industrial 2020. How does a briquette machine work: Types and making process [Online]. Available: https://briquettesolution.com/howdoes-a-briquette-machine-work-types-and-making-process [Accessed on: $17 / 10 / 2020]$.

Merete, W., Haddis, A., Alemayehu, E. and Ambelu, A. 2014. The potential of coffee husk and pulp as an alternativesource of environmentally friendly energy. East Afr. J. Sci, 8: 29-36.

Miranda, T., Montero, I., Sepúlveda, F., Arranz, J., Rojas, C. and Nogales, S. 2015. A review of pellets from different sources. Materials, 8: 1413-1427.

Mu'az1, N.M., Dambatta, M.S., Tukur, S.A., Abdullahi, B. and Abdullahi, U. 2016. Effects of Using Rice Husk and Paper Pulp as Organic Binding Agents on Calorific Value of Biomass (Sawdust) Briquettes. $2^{\text {nd }}$ National Engineering Conference, ACICON, December 2016, Faculty of Engineering, Bayero University, Kano, Nigeria, pp.1-5.

Njenga, M., Karanja, N., Jamnadass, R., Kithinji, J., Sundberg, C. and Jirjis, R. 2013. Quality of cooking fuel briquettes produced locally from charcoal dust and sawdust in Kenya. J. Biobased Mater. Bioenergy, 7(3): 315-322.

Okegbile, O.J., Hassan, A.B., Mohammed, A. and Irekeola, B.J. 2014. Effect of starch and gum Arabic binders in the combustion characteristics of briquette prepared from sawdust. Int. J.Sci. Eng. Res., 5(3): 1005-1009.

Onukak, I.E., Ibrahim, A., Mohammed, D., Alewo, O., Ameh Stanley, I.R., Okoduwa, I.D. and Opeoluwa, O.F. 2017. Production and characterization of biomass briquettes from tannery solid waste. Recycling, 2(17): 1-19.

Ortíz, L., Tejada, A., Vázquez, A. and Piñeiro, G. 2013. Use of Forest Biomass Produced by the Monte-Industria Chain. Part III: Production of Densified Elements. CIS-Madera Magazine, pp. 17-32.

Prasityousil, J. and Muenjina, A. 2013. Properties of solid fuel briquettes produced from rejected material of municipal waste composting. Procedia Environ. Sci., 17: 603-610.

Rabbani, M.G., Sattary, C.T., Mamun, M.R.A., Rahman, M.M. and Khan, M.N.H. 2017. Performance analysis of non-renewable energy in Bangladesh. Indones. J. Electr. Eng. Comput. Sci., 5(2): 290-298.

Romallosa, A.R.D. 2017. Quality analyses of biomass briquettes produced using a jack-driven briquetting machine. Int. J. Appl. Sci. Technol, 7:8-16.

Romallosa, A.R.D. and Kraft, E. 2017. Feasibility of biomass briquette production from municipal waste streams by integrating the informal sector in the Philippines. Resources, 6: 12-18.

Rubio, B., Izquierdo, M.T. and Segura, E. 1999. Effect of binder addition on the mechanical and physicochemical properties of low-rank coal char briquettes. Carbon, 37: 1833-1841. 
Zafar, S. 2016, Role of Biomass Energy in Rural Development [Online]. Available: https://www.bioenergyconsult.com/biomass-energy-ruraldevelopment/ [Accessed on: 27/10/2020].

Scarlat, N., Dallem, J.F., Monforti-Ferrario, F. and Nita, V. 2015. The role of biomass and bioenergy in a future bio-economy: Policies and facts. Environ. Develop., 15: 3-34.

Shafie, S.M., Mahlia, T.M.I., Masjuki, H.M. and Ahmad-yazid, A. 2012. A review on electricity generation based on biomass residue in Malaysia. Renew. Sust. Energ. Rev., 16: 5879-5889.

Stolarski, M.J., Szczukowski, S., Tworkowski, J., Krzyżaniak, M., Gulczyński, P. and Mleczek, M. 2013. Comparison of quality and production cost of briquettes made from agricultural and forest origin biomass. Renew. Energ., 57: 20-26.
Tumuluru, S.J., Christopher, W.T., Kenny, K.L. and Hess, J.R. 2010. A Review on Biomass Densification Technologies for Energy Application. Idaho National Laboratory: Falls, Idaho.

Tumuluru, S.J., Wright, C.T., Hess, J.R. and Kenney, K.L. 2011. A review of biomass densification systems to develop uniform feedstock commodities for bioenergy application. Biofuels Bioprod. Bioref, 5: 683-707.

Udehl, B.A. and Kidak, R. 2019. The excessive use of fossil fuel and its impact on climate change in Africa. Curr. J. Appl. Sci. Technol., 32(5): 1-4.

Zhang, Y., Obrist, D., Zielinska, B. and Gertler, A. 2013. Particulate emissions from different types of biomass burning. Atmos. Environ., 72: $27-35$. 